\title{
Maximumtarieven onder de gemiddelde kosten?
}

\author{
In 2017 hebben we onze boeken open gedaan voor de Nederlandse Zorgautoriteit (NZa). Dat moet \\ ook, want niet meedoen is verboden. Onze boeken hebben geen recht op privacy en dat is ook niet \\ nodig. We werken met publiek geld, dus dan mag van ons ook gevraagd worden dat we meewerken \\ aan de instandhouding van het stelsel. Maar waar leidt dat toe?
}

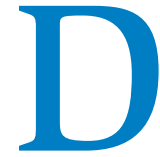

e NZa moet een tarief vaststellen en we hebben geen marktprijs. We hebben een periode gesproken van een markt, maar dat is natuurlijk niet zo. Een marktprijs komt immers niet tot stand in een verhouding, waarin partijen geen vrije keuze hebben, maar juist afhankelijk zijn van elkaar. Het tarief wordt feitelijk eenzijdig vastgesteld door het zorgkantoor. De bandbreedte van de kortingen wordt ook bepaald door het zorgkantoor. We zijn eigenlijk gesubsidieerde instellingen, die op basis van prestaties worden bekostigd. We hebben geen markt en we hebben geen marktprijzen. Maar dan heb je dus wel een andere bron nodig om de kosten te normeren. Vandaar het kostprijsonderzoek.

$\mathrm{Nu}$ is er iets bijzonders aan de hand. De NZa heeft de maximumtarieven voor 2016 vastgesteld. Zorgkantoren verlagen dat naar circa $96,5 \%$ met als argument geld tekort bij de Wlz-kas. Zorgaanbieders passen zich daarop aan door te werken met een budget van 96,5\% . Neen, nog iets lager, want uit voorzichtigheid, om de bank te vriend te houden en vermogen in stand te houden, wordt ook nog een marge gerealiseerd. Ongeveer $1,5 \%$. Eigenlijk bewegen onze kosten zich dus op een niveau van $95 \%$. Vervolgens meet de NZa in 2017 opnieuw de kosten. Dan kom je dus als het goed is ook op kosten die gemiddeld op $95 \%$ van het tarief liggen. Die gemiddelde kosten worden vervolgens omgezet tot een nieuw tarief voor 2019. Dat gemiddelde is dan ineens een maximum.
Gert Kwakernaak, manager Financiën en Informatievoor ziening GemivaSVG Groep
Afgezien van prijsindexeringen, hebben we dus een maximumtarief dat $5 \%$ lager ligt dan het oude niveau. Als de zorgkantoren vervolgens opnieuw 3,5\% korten en de zorgaanbieders gaan 1,5\% resultaat realiseren, dan zitten we niet meer op $95 \%$, maar op $90 \%$. Samengevat, als op basis van gemeten kosten het nieuwe maximum wordt vastgesteld, dan boeren we $5 \%$ achteruit (zie de tabel). In eerste instantie geldt dat voor de zorgaanbieders, maar die vertalen dat door in een verlaging van de kosten. Dan gaat dus ook de zorg achteruit.

Dat kan toch niet waar zijn? Komen die kosten inderdaad 5\% lager uit dan het NZa-tarief? Neen, dat is het verrassende. In werkelijkheid kwamen ze juist iets hoger uit. Hoe kan dat? De verklaring zou zijn dat het resultaat volledig aan de kapitaallasten zou zijn toe te schrijven. Dat lijkt toch wat al te wild. Een deel van het resultaat van 2016 zou kunnen, maar 5\% van de omzet overhouden op het gehele resultaat aan de omzet kapitaallasten (circa 15\% van de omzet), dat is niet logisch. Zijn er nog andere verklaringen of bronnen?

Voor 1 juli 2018 moet de NZa de herijkte tarieven voor 2019 publiceren. Dat wordt spannend. Volgens de systematiek gaan we er $5 \%$ op achteruit. Met de (KPMG) rekenmachine van het kostenonderzoek komen ze in werkelijkheid juist hoger uit.

Er zijn drie vragen waar ik graag een antwoord op wil hebben.

1. Waarom komen de werkelijke kosten hoger uit dan verwacht?

2. Waarom worden gemiddelde kosten bij een herijking geen gemiddelde, maar maximumtarieven?

3. Wat is nog de ratio voor een maximumtarief van zorgkantoren lager dan $100 \%$ ?

Tarieven worden ons feitelijk opgelegd en betaald uit belastingen en premies. Dan mag het geen black box zijn. De Nederlandse Zorgautoriteit moet een degelijk verhaal leveren bij de tarieven. De autoriteit moet zijn naam waar maken. 